\title{
Poetry, Resistance, World-Literature: Adília Lopes and Marie Buck
}

\author{
Paulo de Medeiros \\ University of Warwick
}

\begin{abstract}
This essay begins an exploration of how poetry functions within the field of world-literature, drawing specifically on the Warwick Research Collective's Combined and Uneven Development: Towards a New Theory of World-Literature and reflecting comparatively on the poetry of Adília Lopes and Marie Buck. Even though there are many differences between the two authors and their works, one common feature of their poetics is the deployment of poetry as a form of resistance. As such, both can be seen as especially significant so as to probe into the condition of poetry within a conceptualization of world-literature understood as the literature of the capitalist world-system. As the essay argues, both Adília Lopes and Marie Buck register specific conditions of oppression within a capitalist, patriarchal, society and offer ways to contest them.
\end{abstract}

Keywords: Adília Lopes, Marie Buck, World-Literature, Resistance, Warwick Research Collective

Resumo: Este ensaio inicia uma exploração de como a poesia funciona dentro do campo da literatura-mundial, baseando-se especificamente no volume Combined and Uneven Development: Towards a New Theory of World-Literature, publicado pelo Warwick Research Collective. A partir daí o ensaio esboça uma análise comparativa de Adília Lopes e Marie Buck. Não obstante as variadas diferenças entre as duas autoras e os seus respectivos poemas, o modo em como no caso de ambas se pode constatar uma poética de resistência é um ponto comum e saliente. Consequentemente, tanto a poesia de Adília Lopes como a de Marie Buck constituem casos significantes na elaboração da condição da poesia em relação a uma conceptualização da literaturamundial enquanto literatura do sistema-mundial capitalista. O ensaio sugere esta prática poética como 
expressão de modos de registro de condições específicas de opressão capitalista e patriarchal, assim como da sua contestação.

Palavras-chave: Adília Lopes, Marie Buck, Literatura-Mundial, Resistência, Warwick Research Collective

Escrever um poema

é como apanhar um peixe

com as mãos

Adília Lopes, "Arte Poética"

Today I would like to discuss something apparently simple and yet, at least as I see it, extremely complex. Like Adília Lopes, I am tempted to say, "Ninguém me diga que as coisas são simples / a minha história é tão complicada" (2009: 25). Things, in this case, poetry and its relation to world-literature ${ }^{1}$ as a form of resistance, which is what preoccupies me at the moment, are indeed, or ought to be, simple. And yet, our history, as well as that of the various imbrications of the concepts associated with those terms, is complicated. Even though poetry constantly appears in most discussions of world literature, the ways in which poetry can, or should, be conceived in terms of world literature as a field (and as such usually conceptualized within the disciplinary boundaries of Comparative Literature), or as part of a world-literary system, are very scarce and for the most part indirect. To speak of 'world poetry' is not the same as considering how poetry functions as world literature. World poetry, basically, must refer to all of the poetry, everywhere in the world, at any time and in any language. To start thinking about poetry, or a certain kind of poetry, as part of a world-literary system, requires criteria for inclusion or exclusion in any given world-system. If by that one would simply mean the same as all the poetry in the world, I am not sure that anything would be gained in the categorization at all. Why not just refer to poetry, in that case, simply as poetry? I am principally interested in highlighting a political aspect of poetry, which I consider to be crucial for our very understanding of the notion of poetry, and how it 
relates to notions of world-literature, conceptualized, foremost, as the literature of the modern world-system as proposed by the Warwick Research Collective (2015), which is to say, of the modern capitalist system (2015:8). This does not in any way restrict the poetry to be considered to the West as capitalism, if nothing else, was always a global phenomenon from its inception. At the same time, however, it does delimit the poetry to be considered to the modern period, however one understands it to be, from the sixteenth-century onwards and with special emphasis on the period from the nineteenth-century up to the present. What it does not is restrict the poetry to be considered in terms of language or on whether or not such poetry is widely known internationally, something I will want to return to further on. From the outset then, in this essay I am especially concerned with the imbrications of poetry with politics and how some poetry enacts, performs, or opens up a form of resistance to hegemonic power. This, then, is primarily an attempt at intervening critically on the debate on poetry and world-literature, drawing on a few concrete examples as simple case studies. In order to do so, in this brief essay I propose looking at several poems by two contemporary authors, Adília Lopes and Marie Buck. Although a more detailed comparison of the two and their respective poetics is a task for future writing, my hope is that this essay might serve as a first sketch. The two writers are clearly distinct, one writing from a quiet neighbourhood in Lisbon, the other from the United States (although this too is not so simple of course). One, Adília Lopes, with a long trajectory that has evolved from a sheer, raw, defiance, exhibited in her first book Um Jogo Bastante Perigoso (1985) to a composed, even if not serene, masterful game of cat and mouse with the reader, that seems to have become so much smoother with time, yet has lost none of its bite: "Antigamente havia / a casa de estar / e a casa de jantar / e havia fome / como hoje" (2018: 77).

The other, Marie Buck, younger (born in 1982), has three published books up to now. The latest, Goodnight, Marie, May God Have Mercy on Your Soul, reveals a mordant irony that is close to Adília Lopes', except that more violent; and a very similar capacity to draw on popular culture and refer to memory in a continuous re-invention of the self that never ceases to show its fangs and rip through the veneer of bourgeois illusion and self-delusion: "Sometimes in the dead of night / I wake up to find my tongue's become a thin metal rod ... (Buck, "Both of My Touches" 2017, 105). And then there is kitsch, or rather the use of kitsch, 
and how this relates to what I am tempted to call "o avesso da poesia", poetry's reverse, or poetry's inside out, poetry's adverse, that both questions and explodes its traditional affiliations with bourgeois culture and the individual Self, in its incessant masquerade, and stands in as witness to the age's ravage of any form of justice and the meaning of being human.

Before going any further, I want to dispel concerns that I am about to embark on a use of poetry strictly for my own, ideological, purposes. Rest assured, I take heed in Adorno's well-known caution, in his lecture on "Lyric Poetry and Society", that he first delivered for the radio in the American Sector of Berlin in 1957, to assuage fears that a political (Adorno calls it "sociological") reading of poetry would aim at destroying the poem for the dubious advantage of imposing an intellectual, distorting, and destroying, stamp on "that most delicate, the most fragile thing that exists" (Adorno 1991: 37). With Adorno, I too believe that "the substance of a poem is not merely an expression of individual impulses and experiences. Those become a matter of art only when they come to participate in something universal by virtue of the specificity they acquire in being given aesthetic form" (Adorno 1991: 38). The poetry of both Adília Lopes and Marie Buck, I would argue, testifies to this at every step as both poets express a form of resistance that is both aesthetic, in its defiance of established norms, and intrinsically political in its denouncing of the vast spread of inequality and cruelty characteristic of our late capitalist world. Indeed, still with Adorno - even if for some who might have grown only in the facile vapidity of what some call postmodernity (falsely attributed to the work of Adília Lopes) or for those now jumping on the bandwagon of what they call post-critique, it might seem hopelessly dated, I would maintain that,

The universality of the lyric's substance, however, is social in nature. Only one who hears the voice of humankind in the poem's solitude can understand what the poem is saying; indeed, even the solitariness of lyrical language itself is prescribed by an individualistic and ultimately atomistic society, just as conversely its general cogency depends on the intensity of its individuation. For that reason, however, reflection on the work of art is justified in inquiring, and obligated to inquire concretely into its social content and not content itself with a vague feeling of something universal and inclusive. (Adorno 1991: 38) 
I will seize on Adorno's reference to "the universality of the lyric's substance" and his subsequent derision of the vacuous and empty use of the term "universality" by would-be defenders of lyric poetry's supposed innocence of the world, to introduce the third referent of this essay, the notion of world-literature, and poetry's space in it. Following on the work of the Warwick Research Collective, the definition of world-literature that I am using, sees it "as the literature of the world-system - of the modern capitalist world-system, that is" (WReC 2015: 8). From this perspective, other traditional notions of "world literature" necessarily appear more expansive and more reduced. More expansive because the traditional canon of what usually is referred to as great literature knows no boundaries, except those imposed by prevailing norms of aesthetic judgment, which, traditionally, even if now we see some slight change, have privileged almost exclusively a few western works, usually by men, deemed to be geniuses, such as Goethe. And more reduced, precisely because of those norms. Poetry, although always included in some form or another in the canon of a traditional "world literature" - think of a Gilgamesh or a Homer, a Camões, or a Milton, a Baudelaire or a Hölderlin - only too often has appeared more as a reinforcement of such norms, both when seemingly effortlessly included in the discussion of What Is World Literature? such as practiced by David Damrosch, or even when specifically singled out for analysis as is the case with the recent essay by Boris Marlov, "Lyric Universality". This latter, tellingly, even if it puts forward lyric's imbrication in society, already literally brackets the "world" in its very first subheading: "Lyric and (World) Literature". This has a peculiar, but only too familiar, effect of creating a pleonastic, statement, for how can one conceive of "Lyric and Literature" when "lyric", even if not confined to the literary, is one of its constituent parts (Maslov 2018: 133). To follow on the premises presented by the WReC, understanding poetry, lyric or otherwise, as part of world-literature, must start by addressing the multiple ways in which poetry registers and represents the modern world and this, I suggest, is precisely what the texts of both Adília Lopes and Marie Buck so insistently do.

Both Adília Lopes and Marie Buck are extremely clear about the fact that their poems are political and insist on recognition of that fact. Rosa Maria Martelo (2010) and Lúcia Evangelista (2011) have written about this in relation to Adília Lopes and argued to see her 
poetics as one of resistance. Like Rosa Maria Martelo, I too accept Adília Lopes's comments literally:

\begin{abstract}
Na sua poesia, Adília põe em comum essa vulnerabilidade, procurando que a comunidade a integre sem condições, e a torne partilhável. É por isso que leio completamente à letra esta frase do texto de apresentação de $A$ Mulher-a-Dias: “(...) os meus textos são políticos, de intervenção, cerzidos com a minha vida". É ainda por isso que a ponho em relação com o fim do poema comentado por Adília no seu depoimento para a Relâmpago: "E a minha face / é desassombrada / as sombras / não são minhas". Em 2001, na Fundação Eugénio de Andrade, respondendo a uma pergunta que Ihe tinha sido feita, Adília Lopes disse algo de semelhante: “eu não sou provocadora, este tempo é que é provocador". (Martelo 2010: 3)
\end{abstract}

The two poets continuously engage in complex strategies that question what one may understand as the individual, the Self, or subjectivity. These "games", utterly serious at any rate, even if not always dangerous, are never vain, merely clever, or entropic. Indeed, if anything, they are the opposite of any form of entropy. However, this is not to say that the poets necessarily engage in any form of "autobiographical pact" with the reader. Here, I must diverge, even if only slightly, from Martelo and Evangelista. In my reading, even when the poems appear to plead more directly with us to see them as an expression of an individual, identifiable self that would correspond with the author, they are always metapoetic already. This, whether through the deployment of memories from a specific, individualized, past, or by the use of the proper name - but of course in the case of Adília even that too is above all a fictional construct, the very image of the "poetisa", and as such as liable to be explored, exposed, and disassembled. Rather, my suggestion then is that these "games" - beyond expressing a profound alienation ensuing from modernity and the mounting threats on any form of community that both writers see as fundamental for their own existence and survival as well as that of others - constitute foremost a form of resistance that does not cease to expose the perfidious ways in which capital keeps extolling the individual and freedom only to more easily impose its implacable regime and subjugate all of us by driving us from each other and from ourselves: "Eu sou a luva / e a mão / Adília e eu / quero coincidir / comigo mesma" (Lopes 2009: 337). 
In this respect it is noteworthy, both surprising and to be expected, that there is a coincidence between the two poets, in spite of their different locations and generations. The differences are important too, and register the inevitable variation between them and their respective societies in terms of both the proliferation of computer games and references, the catastrophic use of opiates, or the wide spread violence that permeates current life in the USA to a degree that it still does not in Portugal. Or at least the scale is different. Yet, what I find holds more importance are precisely the points of convergence, be it the frequent use of cats (and their multiplication), the conscious use of popular culture, the deliberate conflating of the intensely lyrical with the more mundane prose and the biting irony that is never a reflection of any assumed intellectual superiority, but rather an expression of a lucidity that is borne out of pain and does not hide it. Very briefly, I would like to turn to the question of the use of pop culture that dovetails inevitably into the realm of kitsch as both are extremely important in the configuration of these poets' poetics. Let me start with Marie Buck and use some of the comments made by Josef Kaplan when reviewing her work, as they call out some of the key issues I want to address:

\footnotetext{
Marie Buck's poems describe a more perverse and therefore honest Americana, where, alongside casseroles and Lassie Come Home, everyone is also constantly drooling and watching you urinate, and hallucinated reptilian surrogates hungrily stalk the peripheries of your family vacation. These and other anecdotes unfold through an aperture of shifting literary filters - sometimes memoir, sometimes surrealist sci-fi fantasy, often both - that, like a form of spirit photography, makes present a frighteningly uncertain image of our current political situation..." (Josef Kaplan, back cover of Good night, Marie 2017)
}

Whereas Kaplan does not hesitate to read Marie Buck's poems as political and as being more "honest" about the contemporary conditions of life in the United States, other critics still hesitate. Aaron Wilson, for instance, writing on Portrait of Doom, Marie Buck's second book (2015) starts by affirming, only to immediately deny, the poems' political nature: "Portrait of Doom is, for all intents and purposes, a book of political poems. But at the same time, it's not" (Wilson "The Liberty of Horrors", Jacket 2, 2019). Not coincidentally, one can also detect a similar unease with various Portuguese critics in relation to Adília Lopes's poetry, as Rosa Maria Martelo has already pointed out (2010: 214). There is indeed a 
tendency to infantilize, ignore, or even pervert Adília Lopes' texts, in an attempt at a facile and futile domestication of their critical force. This is even more problematic with regards to the poet's own life. Somehow, critics and journalists feel entitled to comment on personal aspects, even if only as an attempt to deal with the unease that Adília Lopes does not cease to cause as she shatters the boundaries of bourgeois decency and privacy. Yet, she never does so just as mere provocation - far from it - but precisely in order to rupture the veil of complicity so many critics still let themselves be ensnared by. Even when critics assume an enlightened air, pretending to cut through all of the "mediatic" aspects of what they designate as a carefully orchestrated performance, they still fall back into the old clichés, as can be seen in the very title of Joana Emídio Marques' article on Manhã, "Adília Lopes: A louca da casa", which is continued in the oh-so sophisticated question of the subtitle: "Foi a poeta-pop, a poeta do kitsch, a poeta-mulher-a-dias, a poeta que não fornica, a poetaanedota, a poeta dos tops, a anti-poeta. Trinta anos e muitos livros depois, quem é Adília Lopes?" (Marques 2015). Whereas such attention-grabbing headings are directed clearly at a certain kind of public, and thus perhaps not worthy of further attention, I am not even reaching down for those who simply express their envy under the cover of being outraged by what they designate as the "show". But one should not for a moment lose sight that what such misreadings harbour is not the genuine discomfort that might still have troubled someone like Osvaldo Silvestre ("As lenga-lengas da menina Adília" 1999) without ever making him lose sight of the importance of Adília Lopes' work; rather, at the core of such foolery is a form of complicity, blind or not, with the hegemonic forces of late capitalism, made only the more perfidious for its claims to the contrary.

This is how Marie Buck expresses herself on the political nature of her poems when asked about "theoretical concerns behind [her] writing:

...[R]ight now I am very interested in thinking about political hope and disappointment - how these affects work, how they might play into the formation of collectivities. Right now there is a lot of up and down, social movements springing up but only briefly, heavy repression, lack of organization. I'm interested in thinking about contemporary hope and disappointment through thinking about the 1970s and 1980s". (Interview with Harriet Staff July 2015) 
One could, I suggest, transfer these comments to Adília Lopes and her use of the past, and very specifically the mid sixties to late seventies (think of all of those photos of her from 1964, but that must remain suspended, in brackets as it were, for the moment). Let me try to take the argument further by looking briefly at two poems. This, for instance, by Marie Buck, taken from Portrait of Doom:

\section{Pain Funnel}

Welfare mom with kids

Recent high school graduate

College freshman dropout

Pregnant ladies

Recent divorce

Military - active and retired

Low self-esteem

Low-income jobs

Vocational rehabilitation

Experienced a recent death

Experienced a recent birth

Empty nest syndrome

Recent marriage

Relocation

Career change

Upgrade skills

Physically / mentally abused

Recent incarceration

Drug rehabilitation

Dead-end jobs - no future

College credits $-2+$ years

Living with multitude of families

Living with parents

Living with significant other

Fired /lay off

Self-employed with no benefits 
Tell me more about that.

Can you be more specific?

What have you tried to do about that?

Have you tried to fix it?

What has it cost you?

How do you feel about that?

Does the prospect have enough pain to qualify for the next step?

Whose life will this impact, beside you?

Who will be the most proud at your graduation?

Reality check! So why haven't you taken these steps yet?

(Buck 2015)

Let us agree to leave aside easy and empty readings that would claim this as yet another exponent of postmodernism's love for lists, especially if random, of banal objects, just as we can safely dismiss the view of such arrangements, or litanies, in Adília Lopes ("lenga-lengas", as Osvaldo Silvestre once ironically but somewhat dismissively opined), as an enactment of the banal quotidian for the gaudy delight of the middle classes. No, neither Adília Lopes nor Marie Buck have any remote likeness to Joana Vasconcelos and her savvy appropriation of working-class culture - and labour - to ingratiate herself with the eversucceeding coteries of nouveau rich, Portuguese and otherwise, while laughing all the way to the bank. We could of course focus on the way the poem functions as a collage of found text, internet derived, google searches, or such fare. Such a focus on form might at least lead us to see the way in which the poem, for all its deceptive simplicity, bordering on the flatness of platitudes - "Tell me more about that ... How do you feel about that?" - actually assembles a cartography of precarity and submission, put forth as different kinds of individual and collective life, all subject to varying forms of cruelty, here foremost as a type of bureaucratic dehumanization: "Does the prospect have enough pain to qualify for the next step?" From the many poems of Adília Lopes that could be invoked, here just this brief one, already cited, in all of its stark accusation: "Antigamente havia/ a casa de estar/ e a casa de jantar/ e havia fome/como hoje" (Lopes 2017: 77). 
I would now like to refer further to two specific poems. Because I think they illustrate, beyond a doubt, the similarities in the poetry of both Adília Lopes and Marie Buck, their commitment to expose cruelty, perversion, and abuse; and how their regard, more than ironizing, even if it does that too, functions as a form of resistance; a resistance that remains absolutely realist, yet does not completely let go of hope in spite of suffering. The text by Adília Lopes, already commented on by Rosa Maria Martelo, is taken from Irmã Barata, Irmã Batata (2000):

Em 81 disse à Dra Manuela Brazette, psiquiatra, "Eu sou feia". Ela disse-me "Não é ser feia. Não há pessoas feias. Não tem é atractivos sexuais". Lembrei-me então do homem que em 74, tinha eu 14 anos, se cruzou comigo no Arco do Cego. Lembrei- me do homem, da cara do homem vagamente, mas lembrei-me muito bem do que ele me tinha dito ao passar por mim. Tinha-me dito "Lambia-te esse peitinho todo". Lembrei-me também da meia-dúzia de outros homens que durante a minha adolescência me tinha dito quando eu passava "Coisinha boa" e "Borrachinho". Ainda hoje me sinto profundamente agradecida a esses homens.Pensei que eles estavam a avacalhar, que eram uns porcalhões. Mas quem estava a avacalhar era a Dra Manuela Brazette, ela é que é uma porcalhona. Acho que um homem nunca consegue ser mau para uma mulher como outra mulher. (Dobra 2009: 410)

And part of a poem by Marie Buck:

\section{You Know the Hole You Crawled Out From}

We're living through the second gilded age,

With all that's happening to women right now.

Yeah, you fucking dick.

We're living through the second gilded age.

While doing some dental work on my mouth

My dentist asks me if I have a boyfriend?

Or a husband? And picks up my hand

To see if I'm wearing a ring. 


\author{
Yeah, you fucking dick. \\ I do. \\ I came out of the birth canal \\ Very very quickly. \\ So quickly \\ The nurse almost dropped me. \\ I was already wearing a t-shirt; \\ The t-shirt said, if it ain't pit \\ It ain't shit. \\ I already liked pit bulls. \\ I already liked milk. \\ I withdrew a small mirror \\ From my pocket. \\ And in it \\ I showed the nurse my \\ True face. \\ (Buck, Goodnight Marie: 72-73)
}

The rest of the poem becomes more prone to be read autobiographically as we are shown the hopelessness of growing up in a desolate rural backwater in the USA, at the same time that it adds another meaning to the title of the poem as the "hole" the creepy, abusive, dentist, crawled out from starts to merge with the "hole" the young woman grew up in and longed to escape from, before concluding by repeating the initial invective directed at the dentist: "Yeah, you fucking dick" (Buck Goodnight Marie: 74).

Let me go back to the question of world poetry, of poetry within world-literature and of the world in poetry. As already mentioned, poetry figures in most discussions of world literature without any conceptualization of its role, function, or even form. In most cases, when poetry is discussed at some length, invariably the poetry in cause is either ancient or pre-modern, Homer or Dante, say, or non-western, Persian, or Chinese, for example, or 
both. In a way this constructs a notion of world poetry that both reinforces predominantly canonical authors and privileges pre-modern works, while assuming the semblance of expanding the field of enquiry of world literature. Often, such references and inclusions are simply made without any reflection as to what effect they might have on our understanding of the notion of world literature. One of the earlier, often debated and cited, interventions that takes such a line is Stephen Owen's review of a translation into English of a book of poems, The August Sleepwalker by the Chinese writer Bei Dao, published in The New Republic on 19 November 1990. In it Owen establishes a dichotomy between national poetry and international poetry and he leaves no doubts as to what he prefers. Although Owen recognizes the international - or Western, as he says - success of Bei Dao's poetry, he laments what he perceives as the loss of a sort of grounding in the national tradition, history, and indeed language. This is something Owen would reinforce in a later essay, in which he develops the views expressed incipiently, as it were, in the book review. In "Stepping Forward and Back: Issues and Possibilities for 'World' Poetry" (2003) he writes:

I readily concede that contemporary poetry still operates primarily in the context of national literatures and national languages. If international recognition is a force, it is a force only on the edges of a national literature, pressing in different degrees and different ways. It is, to my knowledge, not a force at all on poetry in English. Cultural power is not evenly distributed, and the poet writing in English (or French) can work in blithe self-confidence regarding the universal adequacy of his or her linguistic community. "International recognition" means recognition by certain centers of cultural power and recognition in English or one of the other international languages. (Owen 2003: 533)

Owen obviously points to an indisputable fact concerning the near hegemony of the English language in the present - his allowance for the possibility of French still enjoying some of the same force is a kind gesture just as his vague reference to "international languages" also admits the possibility of there being something more than just "global" English. However, his adherence to a national paradigm for contemporary poetry is one that surprises. Clearly, if one wants to do a quick check on this and think about Adília Lopes' poetry one could say that given the scarcity of translations, especially into English, she is primarily recognized in Portugal or Brazil. But that already points us in a direction that Owen might not even have considered. As for Marie Buck, at the moment at least, her poetry is 
primarily received in the United States, or possibly in Canada and the United Kingdom as well. The hegemonic effect of English does not seem to have yet kicked in for Marie Buck. Even in England, access to her poetry is still far from widespread. An academic bookseller such as Blackwell's, or the internet giant Amazon, do list her latest book; but trying to buy her previous ones remains difficult and a more mainstream national bookseller such as Waterstones simply does not carry any of her work. Should one want to stick then to criteria such as public recognition, wide availability, and indeed, being translated into other languages, as markers for world literature, either both authors would not be included or, if anything, Adília Lopes, with a much more extensive record of publication, critical attention, and even some translations, would edge closer to such a simple definition of world literature in spite of writing in Portuguese rather than English. But that would be an idea of literature for which I have no use, as it fails, in my view, to account for many other crucial aspects, including the political elements - both in terms of the texts themselves or the conditions of reception - I consider to be fundamental when conceptualizing world-literature.

Owen's emphasis on the national paradigm as some kind of guarantee for the authenticity of poetry is all the more peculiar for its lateness. Even though the fast growing of the field of world literature within the discipline of Comparative Literature or as part of a broader view of English studies was still in its formative stage, such discussions were not unheard of. One could here briefly note that 2003 is also the year of publication of the one book credited with renewing the field and drawing intense attention to it, David Damrosch's What Is World Literature? But perhaps more to the point would be to signal that that book in itself did not come out of a vacuum. Pascale Casanova had also published her influential La République mondiale des lettres already in 1999 (even though the English translation would have to wait until 2007). Sarah Lawall had also brought out an important, and pioneering, collection of essays by diverse authors even earlier, with Reading World Literature: Theory, History, Practice (1994). As part of that collection, Thomas M. Greene's reflection on "Misundertanding Poetry: Teaching Outside the Western Canon" already advances important questions that appear to still not have bothered, or else were taken from a significant different perspective, Owen in either the earlier review or the later essay. Rather than dwell on those, I find it more useful to focus on the fact that for both Owen and 
Greene, some common key issues become very central to any discussion of poetry and world literature. One of these has to do with the question of translation, even of the translatability of poetry; the other, I would suggest, with the differing ways of bridging across cultural difference. For Green, speaking from his position as a Western reader, this is above all a question of striving to find some common, dare one say, universal, human attributes; while always being aware, not just of the depth of cultural and linguistic divides, but also, and perhaps more importantly, of the way in which our own cultural formation always will lead us to experience phenomena in certain determined ways and that we must recognize this even as we try to surpass such conditioning. In other words, no matter how much we may want to embrace cultural difference, it is only honest to remind ourselves about the extent to which our own position in the world shapes whatever epistemology we may deploy when analyzing cultural artifacts.

Before closing this line of reflection, just a brief comment on the issue of language as that is central both to the notion of a supposed national "authenticity" as to the possibility, even desirability of transcending it through translation. In Owen's case, one of his sharpest criticism of the move away from a national understanding of a national poetry - and thus his direct criticism of Bei Dao for supposedly either writing with a translation already in mind or having the good fortune of finding a gifted translator. These objections somehow coalesce when he concludes:

By writing a supremely translatable poetry, by the good fortune of a gifted translator and publicist, he may well attain in the West the absolute pre-eminence among contemporary Chinese poets that he cannot quite attain in China itself. And the very fact of wide foreign (Western) recognition could, in turn, grant him pre-eminence in China. Thus we would have the strange phenomenon of a poet who became the leading poet in his own country because he translated well. The international audience admires the poetry, imagining what it might be if the poetry had not been lost in translation. And the audience at home admires the poetry, knowing how much it is appreciated internationally, in translation. Welcome to the late twentieth century. (Owen 1990: 32)

As a noted sinologist, Owen of course has several advantages over those of us, whether as common readers or even specialists in poetry, who cannot check the original. This, in turn, raises a complex and thorny question relating to the use of languages, and the 
(im)possibility of translation. Much has been, and surely will continue to be, written on this and I will not touch on the question at the moment, noting only that Emily Apter's work on this in Against World Literature: On the Politics of Untranslatibility (2013) extensively covers many of the primary and ancillary issues that are far from being resolved, while Robert J. C. Young, in "World Literature and Language Anxiety" (2013) also goes at it in a concise and very focused manner, especially in relation to postcolonial writing in general and very specifically with Maghreb writers. It might seem that neither Marie Buck nor Adília Lopes would be directly affected by such questions - English is normative globally today and Portuguese, though far from it, certainly falls within the scope of what even Owen refers to as "international languages" by virtue of its function as part of Portuguese imperial and colonial history as well as being used globally after independence. The issue of multiple and intersecting world-systems immediately arises, yet must be deferred to another occasion as it is too complex to be dealt with here. But of course, allied to the question of language anxiety as both authors and Owen also mention questions of politics and of the relative power accorded to nations and their languages. And this brings me to the point of politics and poetry again. Whereas Owen tried to praise what he perceived as the "new" international poetry being produced by Bei Dao (and his translator) for its supposed ability to evade the political, Jacob Edmond, writing in long detail about Bei Dao and the question of world literature, has no difficulty demonstrating how political indeed the poetry of Bei Dao is and how it would have been so perceived by a Chinese audience. As he writes:

Bei Dao has provoked one of the most extensive critical debates about translation, globalization, and national and world literature. Yet what has gone unnoticed is how his appeal to the world and use of allegory address the allegorical readings and translations that produce and repeatedly transform conceptions of the national, the world, and the global. Like the multiple meanings of the terms "world" and "world literature," these readings and translations are inflected by history, ideology, and unequal cultural and economic power relations. Thus a poem describing the isolation and erasure of tradition in the Cultural Revolution comes to be read as an allegory of an international literature without connection to a place, time, people, or language. As the contrasting readings of his work illustrate, allegory not only establishes a correspondence between text and world; it also reveals the gap between the world and our words for it. (Edmond A Common Strangeness, 2012: 97) 
Indeed, even if neither Apter nor Young, Owen nor Edmond, explicitly link the political issues surrounding poetry and literature, they also leave no doubts as to the necessity to always have these in mind. From my perspective, as already noted, beyond a general focus on poetry and the political, I am especially interested in what one could, tentatively, term a poetics of resistance and its place within world-literature. There are many other points to explore, before properly assessing the placement of this kind of poetry in world-literature. As a kind of initial step though, I would like to refer briefly to Adorno and his conceptualization of kitsch since that is so important in the poetics of both Adília Lopes and Marie Buck as I have already mentioned. At one point in his Aesthetic Theory, Adorno points out to an essential antinomy of art in its relation to kitsch:

Kitsch is not, as those believers in erudite culture would like to imagine, the mere refuse of art, originating in disloyal accommodation to the enemy; rather, it lurks in art, awaiting ever recurring opportunities to spring forth. Although kitsch escapes, implike, from even a historical definition, one of its most tenacious characteristics is the prevarication of feelings, fictional feelings in which no one is actually participating, and thus the neutralization of these feelings. Kitsch parodies catharsis. Ambitious art, however, produces the same fiction of feelings; indeed, this was essential to it: The documentation of actually existing feelings, the recapitulation of psychical raw material, is foreign to it. It is in vain to try to draw the boundaries abstractly between aesthetic fiction and kitsch's emotional plunder. It is a poison admixed to all art ... (Adorno 1997: 239)

As is well known, Adorno had no interest in popular culture and, though highly attuned to the sway of kitsch, remained fiercely attached to his attempt to separate it from art. Still in the Aesthetic Theory we also read: "The critique of kitsch must be vigilant, though it takes its toll on art as well. The revolt of art against its a priori affinity with kitsch was one of the essential laws of development in its recent history, and it participates in the destruction of works. What once was art can later become kitsch. Perhaps this history of collapse is the history of the correction of art, its true progress" (Adorno 1997: 315). Obviously, times have changed and perhaps Adorno today might have entertained the notion that some forms of what he viewed as popular art might be as worthy of consideration as canonical high-brow ones. But that is neither here nor there and, in any case, the poetic forms I have been considering might borrow a demotic vocabulary and take 
on the appearance of the ready-made object, but they are not to be confused with popular art. What interests me at this point is rather how, if one inverts Adorno's premise, one might gain a further insight into the poetics of Adília Lopes and Marie Buck. This inversion in no way should be seen as a rejection of Adorno's concerns, but rather as its adaptation in the light of radically altered circumstances as capitalism has evolved from its modern, to its late phase, and even what some now consider to be its spectral phase under full financialization. Or, as Joseph Vogl puts it, 'our task is to understand how the modern finance economy is attempting to come to grips with the world it has created in its image. It is a world in which "the specter of capital" appears as a cipher for those powers from which our present takes its laws' (Vogl 2015: x) ${ }^{2}$. Yes, the critique of kitsch must remain vigilant, perhaps never more than today when capital has managed to use new technologies and people's infinite greed to infiltrate all realms of our lives, more often than not precisely through the deployment of kitsch as a model, goal, and object of unending fascination, be it in the shape of 'individual number one' (also known as Trump) in person, or in the renewed proliferation of national flag-waving (made in China) all across Europe. But as Adília Lopes and Marie Buck show, their use of kitsch transforms it and makes art of it. Yes, Adorno is right in saying that "What once was art can later become kitsch". But so can what once was kitsch become art, and in its registration, exposure, and denunciation of capitalist devastation, point towards survival in the present and the hope for change in the future. 


\section{NOTES}

${ }^{1}$ Following the practice established by the Warwick Research Collective, the writing of "world-literature" with a hyphen is meant to recall its functioning within a world-system, as in Immanuel Wallerstein's proposition in World-Systems Theory (2004). Also, by emphasizing that this system is the capitalist system the WReC simply makes explicit what is already fundamental to Wallerstein's concept.

2 This is an obviously complex and far from resolved question. A good point to start looking further into this might be a Special Issue of the Cambridge Journal of Economics, organized by Giuseppe Fontana, Christos Pitelis, and Jochen Runde, on Financialisation and the new capitalism? In their Introduction they make some of the problems evident:

According to one of its better-known definitions, financialisation is 'the increasing importance of financial markets, financial motives, financial institutions and financial elites in the operations of the economy and its governing institutions, both at the national and international levels' (Epstein, 2001, p. 1). While aspects of financialisation in this broad sense have been a feature of industrialised capitalism for a long time (Argitis and Pitelis, 2008; Orhangazi, 2008; Vercelli, 2017; Fasianos et al., 2018), most of the current literature focuses on specific features of financialisation that have emerged since the 1980s. The proliferation of securitisation and other new financial instruments, together with the substantial expansion of credit to households (Sawyer, 2018), are a particular focus here. There has also been a lot of work on the extent to which the present era of financialisation has coincided with and possibly been facilitated by a parallel 'liberalisation', de-regulation and move to self-regulation of financial markets and the economy more widely, and how these developments have gone hand-by-hand with the rise of globalisation, neo-liberalism and growing inequality. (Palley 2013); (Cambridge Journal of Economics 2019(43): 799) 


\section{Bibliography}

Adorno, Theodor W. (1991), "Lyric Poetry and Society", Notes to Literature, Vol. 1, ed. Rolf Tiedemann, transl. Shierry Weber Nicholsen, New York, Columbia University Press: 37-54.

-- (1997), Aesthetic Theory, London and New York, Continuum.

Apter, Emily (2013), Against World Literature: On the Politics of Untranslatibility, London, Verso.

Buck, Marie (2015), Portrait of Doom, Krupskaya.

-- (2015), Interview with Harriet Staff, "Marie Buck on Collectivity, Star Trek, Portrait of Doom, Political Hope, More", Poetry Foundation, July, https://www.poetryfoundation.org/harriet/2015/07/marie-buck-on-collectivity-star-trekportrait-of-doom-political-hope-more (consultado a 14 de Outubro de 2019).

Buck, Marie (2017), Goodnight, Marie, May God Have Mercy on Your Soul, New York, Roof Books.

Cambridge Journal of Economics. Special Issue on Financialisation and the new capitalism? (2019), eds. Giuseppe Fontana, Christos Pitelis, and Jochen Runde, 43: 799-804.

Casanova, Pascale (1999), La République mondiale des lettres, Paris, Seuil.

-- (2007), The World Republic of Letters, transl. by Malcolm DeBevoise, Cambridge, Mass., Harvard University Press.

Dao, Bei (1990), The August Sleepwalker, transl. by Bonnie S. McDougall, New York, New Directions.

David Damrosch (2003), What Is World Literature?, Princeton, Princeton University Press.

Edmond, Jacob (2012), "Bei Dao and World Literature", in A Common Strangeness: Contemporary Poetry, Cross-Cultural Encounter, Comparative Literature, New York, Fordham University Press: 96-125. 
Evangelista, Lúcia Liberato (2011), Vida em Comum: A Poética de Adília Lopes, Dissertação de Mestrado, Faculdade de Letras da Universidade do Porto, https://repositorioaberto.up.pt/handle/10216/57408 (consultado a 14 de Outubro de 2019).

Greene, Thomas M. (1994), “Misunderstanding Poetry: Teaching Outside the Western Canon", in Lawall, Sarah (ed.) (1994), Reading World Literature: Theory, History, Practice, Austin, University of Texas Press: 69-86.

Kaplan, Joseph (2017), in Marie Buck, Goodnight, Marie, May God Have Mercy on Your Soul, New York, Roof Books.

Lawall, Sarah (ed.) (1994), Reading World Literature: Theory, History, Practice, Austin, University of Texas Press.

Lopes, Adília (2009), Dobra: Poesia Reunida 1983-2007, Lisboa, Assírio \& Alvim.

-- (2018), Estar em casa, Lisboa, Assírio \& Alvim.

Marques, Joana Emídio (2015), “ Adília Lopes: A louca da casa”, Observador, 27 de Abril, https://observador.pt/2015/04/27/adilia-lopes-a-louca-da-casa/ (consultado a 14 de Outubro de 2019).

Martelo, Rosa Maria (2010), “As armas desarmantes de Adília Lopes”, Didaskalia XL: 3.

Maslov, Boris (2018), "Lyric Universality", The Cambridge Companion to World Literature, (eds.) Ben Etherington and Jarad Zimbler, Cambridge, Cambridge University Press: 133-148.

Owen, Stephen (1990), "What is World Poetry", The New Republic, 19 November: 28-32.

-- (2003), "Stepping Forward and Back: Issues and Possibilities for 'World' Poetry", Modern Philology, 100.4: 532-548.

Vogl, Joseph (2015), The Specter of Capital, transl. by Joachim Redner and Robert Savage, Stanford, Stanford University Press.

Silvestre, Osvaldo Manuel (1999), "As lenga-lengas da menina Adília", Posfácio a Adília Lopes, Florbela Espanca Espanca, Lisboa, Black Sun Editores: 37-77.

Wallerstein, Immanuel (2014), World-Systems Theory: An Introduction, Durham and London, Duke University Press. 
Warwick Research Collective (2015), Combined and Uneven Development: Towards a New Theory of World Literature, Liverpool, Liverpool University Press.

Wilson, Aaron (2019), "The Liberty of Horrors", Jacket 2. https://jacket2.org/reviews/libertyhorrors (consultado a 14 de Outubro de 2019).

Young, Robert J. C. (2013), "World Literature and Language Anxiety", in Küpper, Joachim, ed., Approaches to World Literature, Berlin, Akademie: 27-38.

Paulo de Medeiros is Professor of English \& Comparative Literary Studies at the University of Warwick. His book, 'O Silêncio das Sereias: Ensaio sobre o Livro do Desassossego' (Tinta-dachina, 2015) was awarded the PEN Prize (ex-aequo) for best critical study in 2016. Among his current projects are several inquiries into the relationship between poetry and resistance. 